\title{
Mount St. Helens and Santiaguito lava domes: The effect of short- term eruption rate on surface texture and degassing processes
}

\author{
Steven W. Anderson ${ }^{\mathrm{a}, *}$, Jonathan H. Fink ${ }^{\mathrm{b}}$, William I. Rose ${ }^{\mathrm{c}}$ \\ ${ }^{a}$ College of Applied Science and Technology, Black Hills State University, Spearfish, South Dakota 57799-9102, USA \\ " Geology Department, Arizona State University, Tempe, Arizona 85287-1404 , USA \\ ' Department of Geology and Geologic Engineering, Michigan Technological University, Houghton, Michigan 49931, USA
}

Received 22 August 1994; accepted 24 January 1995

\begin{abstract}
In order to assess the effect of eruption rate on the surface morphology and degassing mechanisms of silicic lava fows, we studied surface characteristics and obtained water content and hydrogen isotopic values of samples from flows at the Mount St. Helens and Santiaguito lava domes. We compared the surface textures and inferred degassing processes to short-term extrusion rates and found that when domes are small and eruption rates are high, lava will not completely degas in transit to the surface, allowing additional volatile loss through surface vesiculation which results in the formation of a scoriaceous carapace. When domes exceed a critical size and/or their cooled crusts reach a critical strength, emergence of new magma is impeded, shortterm eruption rates decline, and more thorough degassing can take place leading to smooth-textured flows lacking scoria development. At Mount St. Helens, this transition occurred during the dome's third year, when it grew from 31.8 to $53.2 \times 10^{6}$ $\mathrm{m}^{3}$. Santiaguito attained a comparable state after 2-3 years of growth, and for most of its 70-year history has produced nonvesicular lava. Degassing patterns that combine closed, open, and kinetic processes can be distinguished using isotope data obtained from samples whose positions on a flow and emplacement histories are well-constrained. Evidence for these patterns is most clearly preserved in lavas erupted during early, rapid stages of dome growth. Petrologists and volcanologists seeking to infer magma chamber conditions from the volatile contents of extruded lavas thus need to sample flows early in their emplacement while paying attention to surface texture, position relative to the vent and flow front, and time of emergence.
\end{abstract}

\section{Introduction}

The bulk chemistry of lava flows has commonly been used as an indicator of magma chamber composition, because lava emplacement is thought to be a simpler process than explosive eruption, and because lavas tend to resist erosion better than tephra deposits. Several workers have attempted to extend such correlations to volatile species because magmatic gasses may strongly influence the explosivity of eruptions. However, such

\footnotetext{
* Corresponding author
}

comparisons are made difficult by the multitude of possible degassing mechanisms. In order to more accurately assess future eruptive behavior, several recent studies have focused on the relationships between the distribution of volatiles in a magma body and mechanisms of gas loss during eruption. Hydrogen isotope analyses of water in lava dome samples have been used to infer degassing processes occurring in the source magma chamber and conduit systems (Eichelberger et al., 1986; Newman et al., 1988; Taylor et al., 1983; Taylor, 1986, 1991; Westrich et al., 1988; Dobson et al., 1989; Hoblitt and Harmon, 1993). However, it has 
also been shown that the geometry of a growing lava dome may control its eruption rate and style of gas loss (Fink et al., 1990, 1992; Anderson and Fink, 1989, 1990). Therefore, late-stage degassing mechanisms must be recognized before magma chamber and vent processes can be isolated.

Mount St. Helens and Santiaguito, two of the best documented dacite lava domes in the world, provide an excellent opportunity to compare hydrogen isotopic analyses from extrusions that are similar in composition, crystallinity, and long-term growth rates but different in growth history, lava morphology, short-term growth rates, and eruptive style. Our study suggests that domes can themselves influence short-term growth rates, which in turn control late-stage degassing. Stable isotopic studies of lava dome samples may provide constraints on magma chamber composition, but only after surface processes are fully appreciated.

\section{Eruption rates}

The Mount St. Helens and Santiaguito lava domes both formed after cataclysmic eruptions removed large portions of the host volcano. The Mount St. Helens dome was emplaced beginning in October 1980 after a series of explosions ejected nearly $1 \mathrm{~km}^{3}$ of material and destroyed several earlier domes (Moore et al., 1981). The formation of Santiaguito began 20 years after Santa Maria volcano produced $5 \mathrm{~km}^{3}$ of ejecta in 1902 (Rose, 1972; Williams and Self, 1983). The lavas of both domes are dacites with crystallinities of 3040\% (Rose, 1972, 1987; Cashman and Taggart, 1983).

The Mount St. Helens dome grew to its final volume of $0.074 \mathrm{~km}^{3}$ through a series of nearly 20 separate eruptive episodes between October 1980 and October 1986 (for a review see Moore et al., 1981; Swanson et al., 1987; Anderson and Fink, 1990, 1992). Each episode consisted of a period of endogenous dome inflation lasting from one day to nearly one month followed by a one-day to one-week period of extrusion. Growth intervals were separated by repose periods of one month to one year, except for a period of continuous extrusion and dome growth during most of 1983 and early 1984. Fink et al. (1990) used digital topographic data to calculate the partitioning of endogenous and exogenous volumes associated with each eruptive episode and concluded that a progressively greater fraction of endogenous growth is required to expand the cooled crust to failure as the dome grows larger and stronger. This result was consistent with earlier inferences based on deformation measurements (e.g., Chadwick et al., 1983).

In contrast, the growth of the $1.0-\mathrm{km}^{3}$ Santiaguito lava dome has been uninterrupted since 1922 , with $3-$ 5 -year spurts of relatively rapid extrusion $\left(20-60 \times 10^{6}\right.$ $\mathrm{m}^{3} /$ year $\left.=0.6-1.9 \mathrm{~m}^{3} / \mathrm{s}\right)$ alternating with $10-12$-year periods of slow growth $\left(<5 \times 10^{6} \mathrm{~m}^{3} /\right.$ year $=0.16 \mathrm{~m}^{3} /$ s) (Rose, 1987). Dome inflation and lava extrusion have accompanied both the eruptive spurts and interspurt' periods. The dome is elongate in shape, with 4 distinct vents on its surface (from east to west: Caliente, La Mitad, El Monje and El Brujo)(Fig. 1). The two most recently active vents, Caliente and El Brujo, are separated by a distance of nearly $1 \mathrm{~km}$, with Caliente lying nearly directly above the 1902 explosion crater vent (Rose, 1987). Peléean and vertical pyroclastic eruptions have also occurred at Santiaguito (Rose, 1972, 1987). In addition, several 'Merapi-type' pyroclastic flows have been emitted from the toes of its blocky lava flows (Rose et al., 1977; Rose, 1987).

The average long-term growth rates at the two domes are nearly identical: $0.35 \mathrm{~m}^{3} / \mathrm{s}$ at Mount St. Helens from 1980 to 1986 (Swanson and Holcomb, 1990; Fink et al., 1990), and $0.41 \mathrm{~m}^{3} / \mathrm{s}$ at Santiaguito from 1925 to 1993 (Rose, 1972, 1973, 1987). In a comparison of several historic dome eruptions, Swanson et al. (1987) found an inverse relationship between silica content and long-term growth rate, suggesting that low-viscosity magma is more mobile and can form domes more rapidly. Thus, the similar long-term rates for two dacite domes of comparable crystallinities is not surprising.

Short-term eruption rates were generally much lower at Santiaguito because at Mount St. Helens much of the time used to calculate long-term rates was taken up by repose periods. Using lobe volumes measured from digital elevation maps and observed durations of extrusive episodes, Anderson and Fink (1990) calculated extrusion rates of $1.4-40.3 \mathrm{~m}^{3} / \mathrm{s}$ for individual exogenous dome lobes at Mount St. Helens (Table 1). These rates do not account for the slow rise of magma during the preceding endogenous growth phase. This was a minor process early in the dome's history, but became substantial after 1983 (Chadwick et al., 1988; Anderson and Fink, 1990). If short-term eruption rates are recalculated to include the endogenous growth phase, 


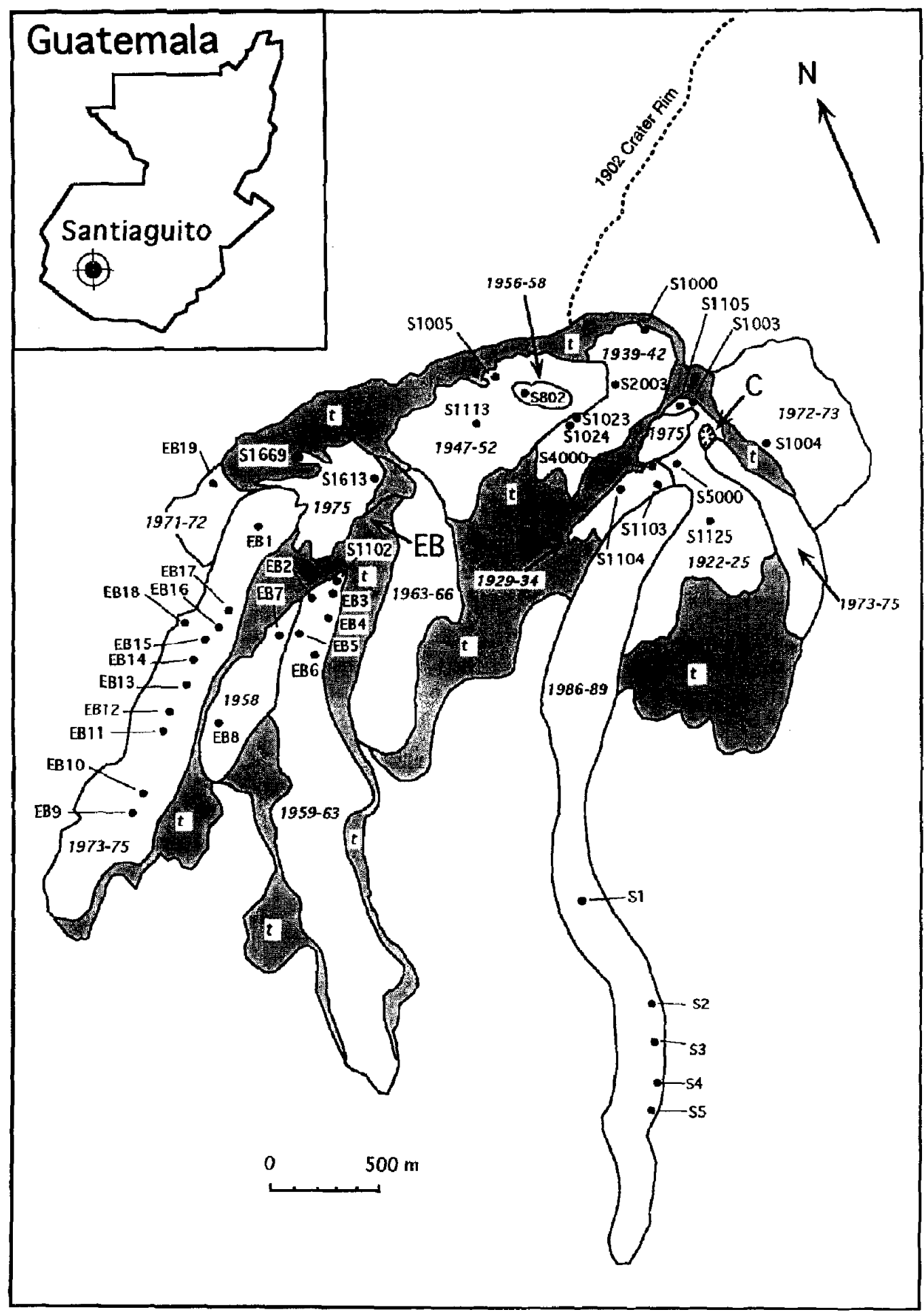

Fig. 1. Map of the Santiaguito lava dome showing the approximate locations of samples collected for water content and isotopic analysis. Approximate dates of emplacement for different portions of dome are shown in italics. $t=$ talus (shaded); $C=$ Caliente vent; $E B=$ approximate location of El Brujo vent. 
Table 1

Extrusion rates of Mount St. Helens dome lobes

\begin{tabular}{|c|c|c|c|c|c|}
\hline Extrusion date ${ }^{\mathrm{a}}$ & $\begin{array}{l}\text { Lobe volume } \\
\left(10^{6} \mathrm{~m}^{3}\right)\end{array}$ & $\begin{array}{l}\text { Length of } \\
\text { extrusion } \\
\text { (days) }\end{array}$ & $\begin{array}{l}\text { Length of inflation and } \\
\text { extrusion }{ }^{\mathrm{b}} \\
\text { (days) }\end{array}$ & $\begin{array}{l}\text { Extrusion rate } \\
\left(\mathrm{m}^{3} / \mathrm{s}\right) \\
\text { (no inflation) }\end{array}$ & $\begin{array}{l}\text { Extrusion rate } \\
\left(\mathrm{m}^{3} / \mathrm{s}\right) \\
\text { (inflation included) }\end{array}$ \\
\hline October 1980 & 1.20 & 1 & 1 & 13.9 & 13.9 \\
\hline December 1980 & 1.92 & 7 & 10 & 3.1 & 2.2 \\
\hline February 1981 & 2.19 & 2 & 4 & 12.7 & 6.3 \\
\hline April 1981 & 1.87 & 2 & 3 & 10.8 & 7.2 \\
\hline June 1981 & 3.49 & 1 & 2 & 40.4 & 20.1 \\
\hline September 1981 & 1.78 & 5 & 6 & 4.2 & 3.5 \\
\hline October 1981 & 1.64 & 3 & 4 & 6.3 & 4.7 \\
\hline August 1982 & 2.51 & 5 & 15 & 5.8 & 1.9 \\
\hline March 1984 & 0.62 & 5 & 10 & 1.4 & 0.7 \\
\hline June 1984 & 0.94 & 16 & 16 & 0.7 & 0.7 \\
\hline September 1984 & 1.53 & 2 & 5 & 8.1 & 3.4 \\
\hline May 1985 & 0.83 & 3 & 13 & 3.2 & 0.7 \\
\hline Extrusion period & $\begin{array}{l}\text { SLobe volume } \\
\left(10^{6} \mathrm{~m}^{3}\right)\end{array}$ & ¿Extrusion days & $\sum$ Inflation + extrusion days & $\begin{array}{l}\text { Average rate } \\
\text { (no inflation) } \\
\left(\mathrm{m}^{3} / \mathrm{s}\right)\end{array}$ & $\begin{array}{l}\text { Average rate } \\
\text { (with inflation) } \\
\left(\mathrm{m}^{3} / \mathrm{s}\right)\end{array}$ \\
\hline Pre-1983 Lobes ( 8 ) & 16.6 & 26 & 45 & 7.3 & 4.3 \\
\hline Post-1983 Lobes (4) & 3.92 & 26 & 44 & 1.7 & 0.9 \\
\hline
\end{tabular}

anderson and Fink, 1990. Only those lobes for which beginning and ending dates of extrusion were directly observed are included.

'Inflation is assumed to begin when shallow seismicity increases abruptly, signalling the cracking of the dome's surface prior to extrusion. Dates based on informal USGS monthly reports for each recorded eruptive episode.

${ }^{c}$ (Lobe volume) /(days of extrusion + inflation).

post-1983 values are then considerably lower than those from 1980 to 1983. At Santiaguito, Rose (1987) calculated eruption rates of $0.6-2.2 \mathrm{~m}^{3} / \mathrm{s}$ during eruptive spurts, and $0.16 \mathrm{~m}^{3} / \mathrm{s}$ during interspurt periods. During its first three years (1922-1925), Santiaguito grew at an average rate of $2.2 \mathrm{~m}^{3} / \mathrm{s}$ and attained a total volume greater than the present day Mount St. Helens dome.

\section{Surface textures and volatile contents}

The appearance of exogenous flows differs at the two domes. Two distinct lava textures are present on Mount St. Helens lobes: smooth lava with less than $30 \%$ vesicles and scoriaceous lava with greater than 50\% vesicles (Swanson et al., 1987; Anderson and Fink, 1990). Scoriaceous lava forms a continuous 1 to 2 meter thick carapace overlying a denser interior and develops where originally smooth, relatively wet lava ( $>0.2$ wt. $\% \mathrm{H}_{2} \mathrm{O}$ ) vesiculates during surface flow
(Anderson and Fink, 1989, 1990, 1992). Although some scoriaceous lava was found on nearly all Mount St. Helens lobes, it dominated the surfaces of all but one of the pre-1983 lobes, whereas smooth lava dominated all but one post-1983 lobe. Anderson and Fink (1990) attributed this shift in lava flow texture to more thorough degassing of magma through the conduit walls and dome prior to its arrival at the surface. Following Swanson and Holcomb (1989), they noted an increase in pre-extrusion deformation of the dome with time, suggesting that lava had more difficulty breaking through the larger extrusion, allowing a longer period of subsurface degassing (Anderson and Fink, 1989, 1990; Fink et al., 1992).

In contrast, Santiaguito lava flows exhibited a substantial scoriaceous carapace only in 1922-1924, with smooth lava (vesicle content $<30 \%$ ) dominating the surface since then. Inspection of 6 post- 1958 lava flows revealed only small $\left(<1 \mathrm{~m}^{2}\right)$ patches of scoriaceous lava, indicating that magma was thoroughly degassed prior to extrusion. The amount of scoria on post- 1958 
flows is generally less than $1 \%$ of the flow surface area, although several flows from the 1970's exhibit more substantial amounts. This temporary increase in scoria production coincided with the shift of extrusion from the more distal El Brujo vent to the main Caliente vent.

Water content and hydrogen isotopic values of Mount St. Helens dome samples varied according to texture, position on the flow, and repose period prior to eruption (Anderson and Fink, 1989, 1990). In any given lobe, smooth lava from near the flow front had a lower water content $(0.08-0.21 \mathrm{wt} . \%)$ than smooth lava from the vent region $(0.16-0.34 \mathrm{wt} . \%)$, suggesting that the smooth flow-front lava represents the dried out top of the magma body that rises slowly as it fractures a path to the dome's surface. Once a pathway is cleared, deeper magma ascends more rapidly, experiences less degassing, and arrives at the dome surface with a slightly higher water content. If lava reaches the surface with a water content greater than approximately $0.20 \mathrm{wt} . \%$, it vesiculates and forms a scoriaceous carapace with a water content of about $0.10-0.15 \mathrm{wt} . \%$. Lava with lower water contents may or may not vesiculate depending on its temperature and cooling rate. Scoria formation is inhibited if new lava emerges through a 'crease structure', a V-shaped fracture that cuts incrementally downward into the flow, rapidly chilling the freshly exposed lava and preventing bubble growth (Anderson and Fink, 1992). The presence of crease structures over the vents of several lobes may account for the higher water contents in some of the near-vent smooth samples.

Anderson and Fink (1989) also compared the $8 \mathrm{D}$ values of Mount St. Helens lava samples of similar texture and flow position with various eruptive parameters. Two trends stand out: (1) lava from lobes emplaced after longer repose intervals is enriched in deuterium, and (2) within individual lobes, relatively dry, smooth lava from the flow front has higher $8 \mathrm{D}$ values than wetter, smooth lava from near the vent. They explained these trends with a three-stage model: lava first experiences closed-system degassing in the chamber during repose periods (Newman et al., 1988; Anderson and Fink, 1989), followed by open-system degassing during ascent and emplacement (Eichelberger and Westrich, 1981, 1984; Taylor et al., 1983; Eichelberger et al., 1986; Newman et al., 1988; Taylor, 1986, 1991; Westrich et al., 1988; Dobson et al., 1989), and a final stage of kinetically controlled degassing upon eruption at the surface. Closed system behavior can be modeled by:

$\delta D^{\mathrm{f}}=\delta D^{\mathrm{i}}-\left(1-F_{\mathrm{w}, \mathrm{m}}\right) 1000 \ln \alpha$

and open-system behavior by:

$\delta D^{\mathrm{f}}=\delta D^{\mathrm{i}}-1000\left(1-F_{\mathrm{w}, \mathrm{m}}^{(\alpha-1)}\right)$

where $\delta \mathrm{D}^{\mathrm{i}}=$ initial $\delta \mathrm{D}$ value of melt, $\delta \mathrm{D}^{\mathrm{f}}=$ final $\delta \mathrm{D}$ value of melt, $F_{w, m}=$ fraction of water remaining in melt, and $\alpha=$ melt-water fractionation factor (Taylor, 1991). In their calculations for the 1980 Mount St. Helens magma, Hoblitt and Harmon (1993) assumed that the bulk water content of the magma was $3 \mathrm{wt} . \%$, the initial deuterium content was -34 per mil, and that $\alpha=1.040$ (Dobson et al., 1989).

Closed-system degassing causes a gradual decline in $\delta \mathrm{D}$ with decreasing water content, open-system behavior leads to a more rapid drop in $\delta \mathrm{D}$, and kinetic gas loss results in an increase or little change in deuterium. Taylor (1991) used the term 'multi-step open/closed system degassing' to describe an intermediate case of incomplete open-system exchange. Variations in repose periods, ascent rates, and cooling rates make it difficult to assign a unique degassing history to an individual lava sample, but a batch of magma erupted in a restricted time period should have a more discernible pattern. The three-stage model accounts for the deuterium enrichment seen in the most degassed smooth samples and in lobes emplaced after longer repose periods.

Sampling of the early Mount St. Helens lobes was not systematic. Anderson and Fink (1989) were able to obtain samples with well-constrained positions from only four of the ten extrusions emplaced prior to 1983 . Only one of these lobes (February 1981) yielded smooth samples taken both near the vent and the flow front; data sets from the other three lobes included a mix of scoriaceous and smooth samples. However, by comparing adjacent samples with contrasting textures, Anderson and Fink (1990) showed that scoria forms by near-surface vesiculation of relatively waterenriched dacite, a kinetic degassing process that results in lower water contents but higher $\delta \mathrm{D}$ values than the corresponding smooth lava. Consequently, in order to compare the isotopes of scoria and smooth lava from the same location, one must assign the scoria a higher water content and lower $\delta \mathrm{D}$ value than the actual measured amounts. Using this approach, we added $0.1 \mathrm{wt}$.\% 

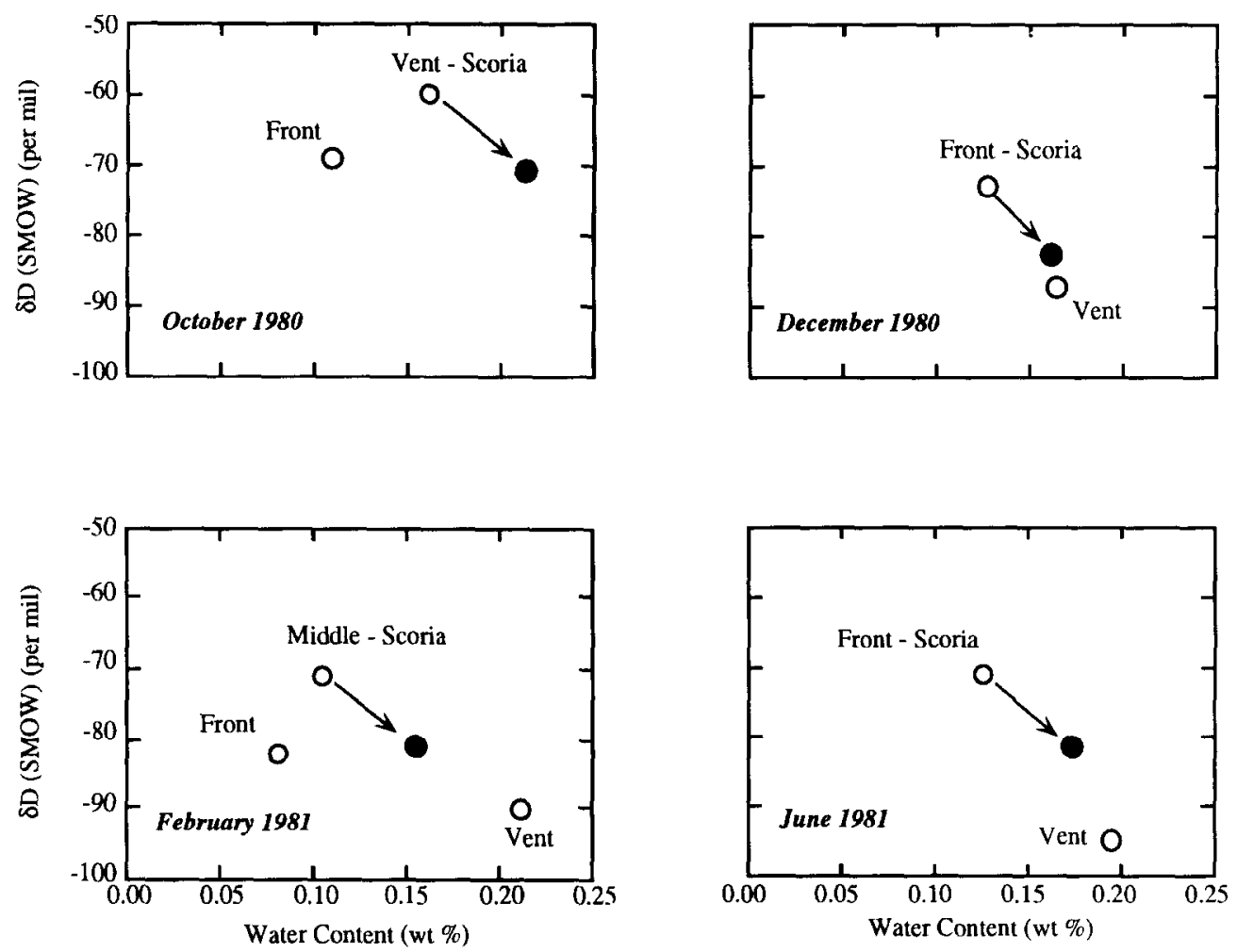

Fig. 2. Plot of $\delta \mathrm{D}$ versus water content for smooth and scoriaceous samples from four early Mount St. Helens lobes. Open circles represent data points. Filled circles are inferred compositions of smooth (dense) lava equivalent to scoriaceous samples, obtained by assuming that scoria formation is accompanied by kinetic degassing, which causes water content to drop by an amount assumed here to be 0.10 wt.\% and $\delta \mathrm{D}$ to increase by an amount assumed to be +10 per mil. After translating the scoria values, each lobe shows a kinetic trend: early, flow-front samples have lower water and higher $\delta \mathrm{D}$ than later, near-vent samples.

to the measured water contents and subtracted 10 per mil from the $\delta \mathrm{D}$ values obtained for the scoria samples. We then plotted these corrected numbers and found that the data from these four pre-1983 lobes are consistent with kinetic trends, with the early flow-front lavas all having somewhat lower water contents and higher $\delta \mathrm{D}$ values than later near-vent samples from the same lobe; mid-lobe samples have intermediate values (Fig. 2).

\section{New water content and hydrogen isotopic data}

Our earlier work demonstrated that different degassing mechanisms can be isolated if lava texture and flow position are noted during sampling (Anderson and Fink, 1989). In order to extend this study to a larger, more structurally complicated dome with several cycles of extrusion, we obtained water content and hydrogen isotopic data for $\mathbf{4 5}$ Santiaguito dome samples (Fig. 1 and Table 2). In addition, we expanded our Mount St. Helens data set by measuring water content and $\delta \mathrm{D}$ for twelve samples spaced at $1-5-\mathrm{m}$ intervals from the vent to the flow front of the smooth-textured October 1986 lobe (Table 3). Whole-rock $\delta \mathrm{D}$ and water content values were determined in the stable isotope laboratory at Southern Methodist University. Samples were crushed to 100 200 mesh, and heated at $120^{\circ} \mathrm{C}$ in a vacuum pump overnight to remove adsorbed water. Samples were then heated to fusion, and $\mathrm{H}_{2}$ was produced by reaction of expelled water with uranium. The water contents were then measured manometrically. The margin of error for the analyses is 3-7 per mil for the $\delta \mathrm{D}$ values and 0.005 wt.\% for the water contents (M. Colucci, pers. commun., 1992).

Like samples from all earlier Mount St. Helens lobes, those from October 1986 showed that smooth lava col- 
Table 2

Santiaguito water content, isotopic and eruption parameter data

\begin{tabular}{|c|c|c|c|c|c|c|c|c|c|}
\hline Sample No. & $\begin{array}{l}\delta \mathrm{D} \text { (SMOW) } \\
\text { (per mil) }\end{array}$ & $\begin{array}{l}\text { Water } \\
\text { (wt.\%) }\end{array}$ & Date & Activity & Type $^{\mathrm{b}}$ & Position ${ }^{c}$ & $\begin{array}{l}\text { Spurt length } \\
\text { (years) }\end{array}$ & $\begin{array}{l}\text { Previous interspurt } \\
\text { (years) }\end{array}$ & $\begin{array}{l}\text { Eruption rate } \\
\left(\mathrm{m}^{3} / \mathrm{s}\right)\end{array}$ \\
\hline S1125 & -121.7 & 0.03 & $1922-25$ & $\mathbf{S}$ & $\mathrm{D}$ & - & 3 & 20 & 2.2 \\
\hline S1105 & -66.4 & 0.24 & $1922-25$ & $S$ & D & - & 3 & 20 & 2.2 \\
\hline S1003 & -91.1 & 0.10 & $1925-28$ & I & D & - & - & - & $<0.16$ \\
\hline S1103 & -101.4 & 0.13 & $1928-33$ & $S$ & $\mathbf{F}$ & NV & 5 & 3 & 0.6 \\
\hline S1104 & -92.2 & 0.14 & $1928-33$ & $S$ & $\mathrm{~F}$ & NV & 5 & 3 & 0.6 \\
\hline S1004 & -94.5 & 0.20 & $1928-33$ & $S$ & $\mathbf{F}$ & DI & 5 & 3 & 0.6 \\
\hline$\$ 1000$ & -102.7 & 0.06 & $1939-42$ & $S$ & $\mathrm{D}$ & - & 3 & 6 & 1.0 \\
\hline$S 2003$ & -96.7 & 0.15 & $1939-42$ & $\mathbf{S}$ & D & - & 3 & 6 & 1.0 \\
\hline S1024 & -105.8 & 0.06 & $1943-48$ & I & $\mathrm{F}$ & DI & - & - & $<0.16$ \\
\hline S1023 & -91.0 & 0.07 & $1943-48$ & I & $\mathbf{F}$ & DI & - & - & $<0.16$ \\
\hline S1113 & -125.8 & 0.07 & $1949-55$ & $\mathbf{S}$ & D & - & 6 & 7 & 1.3 \\
\hline S1005 & -97.9 & 0.14 & $1949-55$ & $S$ & D & - & 6 & 7 & 1.3 \\
\hline S802 & -102.8 & 0.12 & $1956-57$ & I & $F$ & DI & - & - & $<0.16$ \\
\hline EB3 & -93.7 & 0.09 & $1958-63$ & $\mathbf{S}$ & $\mathbf{F}$ & NV & 5 & 3 & 1.6 \\
\hline EB5 & -90.9 & 0.09 & $1958-63$ & $\mathbf{S}$ & $\mathrm{F}$ & NV & 5 & 3 & 1.6 \\
\hline S1102 & -103.1 & 0.10 & $1958-63$ & $S$ & $\mathbf{F}$ & NV & 5 & 3 & 1.6 \\
\hline EB6 & -80.4 & 0.11 & $1958-63$ & $\mathbf{S}$ & $\mathbf{F}$ & NV & 5 & 3 & 1.6 \\
\hline EB7 & -71.4 & 0.14 & $1958-63$ & $S$ & $\mathbf{F}$ & NV & 5 & 3 & 1.6 \\
\hline EB2 & -81.9 & 0.14 & $1958-63$ & $\mathbf{S}$ & $\mathbf{F}$ & NV & 5 & 3 & 1.6 \\
\hline EB8 & -65.3 & 0.16 & $1958-63$ & $S$ & $\mathbf{F}$ & DI & 5 & 3 & 1.6 \\
\hline EB4 & -75.7 & 0.19 & $1958-63$ & $S$ & $\mathrm{~F}$ & NV & 5 & 3 & 1.6 \\
\hline S1229 & -87.6 & 0.04 & $1963-71$ & I & B & - & - & - & $<0.16$ \\
\hline S1669 & -113.3 & 0.09 & $1963-71$ & I & $\mathrm{D}$ & - & - & - & $<0.16$ \\
\hline S1613 & -110.7 & 0.11 & $1963-71$ & I & D & - & - & - & $<0.16$ \\
\hline S2006 & -94.0 & 0.12 & $1963-71$ & I & B & - & - & - & $<0.16$ \\
\hline S550 & -94.4 & 0.12 & $1963-71$ & I & $\mathrm{F}$ & NV & - & - & $<0.16$ \\
\hline S5000 & -109.2 & 0.06 & $1972-75$ & $S$ & $\mathrm{~F}$ & NV & 3 & 3 & 1.0 \\
\hline EB15 & -49.1 & 0.06 & $1972-75$ & $\mathbf{S}$ & $\mathrm{F}$ & MF & 3 & 3 & 1.0 \\
\hline EB 18 & -100.9 & 0.06 & $1972-75$ & $S$ & $\mathrm{~F}$ & MF & 3 & 3 & 1.0 \\
\hline EB 14 & -101.2 & 0.07 & $1972-75$ & $\mathrm{~S}$ & $\mathbf{F}$ & MF & 3 & 3 & 1.0 \\
\hline EB16 & -99.4 & 0.07 & $1972-75$ & $S$ & $\mathrm{~F}$ & MF & 3 & 3 & 1.0 \\
\hline EB13 & -75.3 & 0.07 & $1972-75$ & $\mathbf{S}$ & $\mathbf{F}$ & MF & 3 & 3 & 1.0 \\
\hline EBI9 & -75.1 & 0.08 & $1972-75$ & $\mathbf{S}$ & D & - & 3 & 3 & 1.0 \\
\hline EB1 & -49.9 & 0.09 & $1972-75$ & $S$ & $\mathbf{F}$ & NV & 3 & 3 & 1.0 \\
\hline EB9 & -96.9 & 0.09 & $1972-75$ & $S$ & $\mathrm{~F}$ & DI & 3 & 3 & 1.0 \\
\hline EB17 & -83.1 & 0.11 & $1972-75$ & $S$ & $\mathbf{F}$ & MF & 3 & 3 & 1.0 \\
\hline$\$ 4000$ & -114.9 & 0.11 & $1972-75$ & $S$ & D & - & 3 & 3 & 1.0 \\
\hline EB 10 & -89.1 & 0.11 & $1972-75$ & $S$ & $\mathbf{F}$ & DI & 3 & 3 & 1.0 \\
\hline EB12 & -96.9 & 0.13 & $1972-75$ & $S$ & $\mathrm{~F}$ & DI & 3 & 3 & 1.0 \\
\hline EB11 & -57.1 & 0.15 & $1972-75$ & $S$ & $\mathrm{~F}$ & DI & 3 & 3 & 1.0 \\
\hline S3 & -103.4 & 0.06 & $1986-92$ & $S$ & $F$ & DI & 6 & 6 & - \\
\hline$\$ 4$ & -107.9 & 0.06 & $1986-92$ & $S$ & $\mathrm{~F}$ & DI & 6 & 6 & - \\
\hline S1 & -141.4 & 0.07 & $1986-92$ & $S$ & $\mathrm{~F}$ & DI & 6 & 6 & - \\
\hline S5 & -93.4 & 0.08 & $1986-92$ & $S$ & $\mathrm{~F}$ & DI & 6 & 6 & - \\
\hline$S 2$ & -99.2 & 0.09 & $1986-92$ & $S$ & $\mathrm{~F}$ & DI & 6 & 6 & - \\
\hline
\end{tabular}

a' $S$ ' designates eruptive spurts, ' $I$ ' designates periods between eruptive spurts ('interspurts'). From Rose, 1987 . $^{\text {' }} D$ ' designates sample from endogenous dome growth, ' $F$ ' designates sample from exogenous lava flows, 'B' designates ejected block from explosive activity.' refers to location of lava flow surface samples. 'NV' designates near vent samples, 'MF' designates mid-flow samples, and 'DI' refers to samples

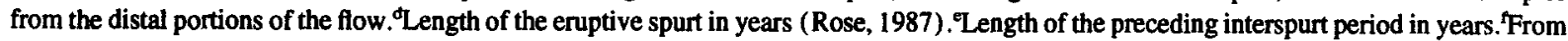
Rose (1987). Long-term rates for the 1986-1992 eruptive spurt are not yet available. 
Table 3

Mount St. Helens October 1986 water content and isotopic data

\begin{tabular}{|c|c|c|c|}
\hline Sample No. & $\begin{array}{l}\delta \mathrm{D}(\mathrm{SMOW}) \\
\text { (per mil) }\end{array}$ & $\begin{array}{l}\text { Water content } \\
\text { (wt. } \% \text { ) }\end{array}$ & $\begin{array}{l}\text { Distance from vent } \\
\text { (m) }\end{array}$ \\
\hline $2 \mathrm{SH} 1086$ & -42.7 & 0.22 & 2.5 \\
\hline 4SH1086 & -67.6 & 0.17 & 6.5 \\
\hline $5 S H 1086$ & -81.0 & 0.11 & 8.5 \\
\hline 6SH1086 & -59.4 & 0.18 & 10.0 \\
\hline 8SH1086 & -98.1 & 0.13 & 16.0 \\
\hline 9SH1086 & -97.7 & 0.11 & 19.0 \\
\hline 10SH1086 & -117.1 & 0.11 & 23.5 \\
\hline $11 \mathrm{SH} 1086$ & -95.2 & 0.13 & 27.0 \\
\hline 14 SH1086 & -88.9 & 0.15 & 48.5 \\
\hline $16 S H 1086$ & -66.0 & 0.17 & 55.5 \\
\hline $18 S H 1086$ & -88.1 & 0.16 & 66.0 \\
\hline 20SH1086 & -86.2 & 0.15 & 70.0 \\
\hline
\end{tabular}

lected closest to the vent tends to have higher water contents than the earliest emplaced lava found near the flow front, although the intervening samples may show considerable scatter (Fig. 3). Isotope data for this wellconstrained, non-vesicular suite suggest an open-system degassing trend with only a hint of a kinetic influence seen in the driest samples (Fig. 4). This dominantly open-system behavior is similar to trends reported for glassy rhyolite flows (e.g., Taylor et al., 1983) but is in marked contrast to those found in pre1983 Mount St. Helens lobes where kinetic effects were more pronounced (Fig. 2). The regularity seen in Figs. 2 and 4 is concealed when the complete Mount St. Helens data set is plotted (Fig. 5). However, the $\delta \mathrm{D}$ values seen in Fig. 5 appear to be bounded below

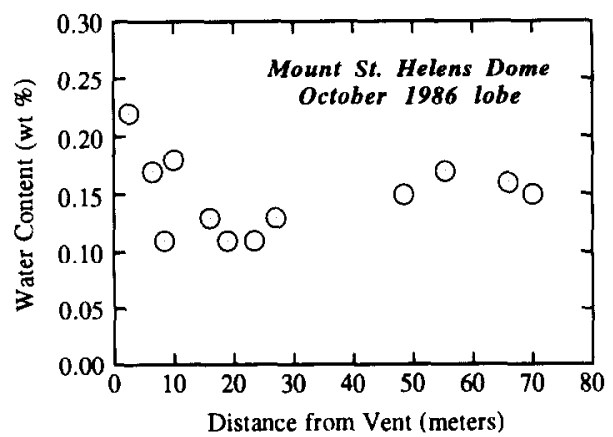

Fig. 3. Plot of water content versus distance from the vent for samples collected from the surface of the October 1986 lobe of the Mount St. Helens dome. The most proximal sample shows a higher water content than the most distal, although intervening rocks exhibit a great deal of scatter. Pairs of samples (flow-front and near-vent) from pre- 1983 lobes all show ventward increases in water content.

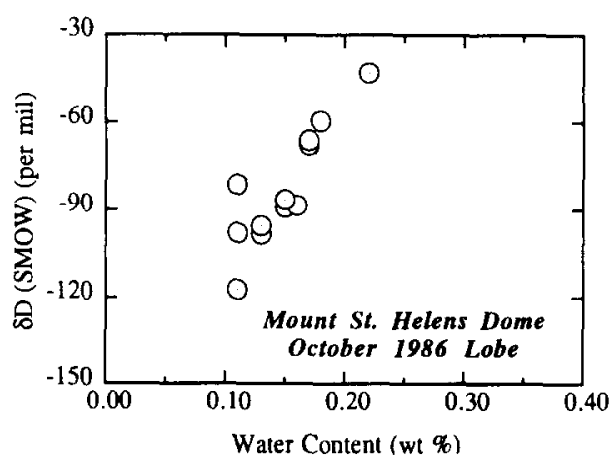

Fig. 4. Plot of $\delta \mathrm{D}$ versus water content for samples from the October 1986 lobe of the Mount St. Helens dome. Nearly all data points lie close to an open-system trend.

by an open-system curve calculated with the values assumed by Hoblitt and Harmon (1993), cited earlier.

Santiaguito samples S-1 through S-5 and EB1 through EB 19 were collected in 1988 and 1990 respectively, whereas all others came from the extensive collection of Rose. Fig. 6 shows data from the entire Santiaguito data set. Although no single trend is apparent (just as in Fig. 5 for the full Mount St. Helens data set), nearly all of the $\delta \mathrm{D}$ values lie above and to the left of the open-system degassing curve calculated for Mount St. Helens. The observed scatter could be due to: incomplete or multi-step open-system degassing (Taylor, 1991); the superposition of several open-system curves for different batches of magma, each of which experienced different degrees of closed-system gas loss before ascent; or the presence of some latestage kinetic effects.

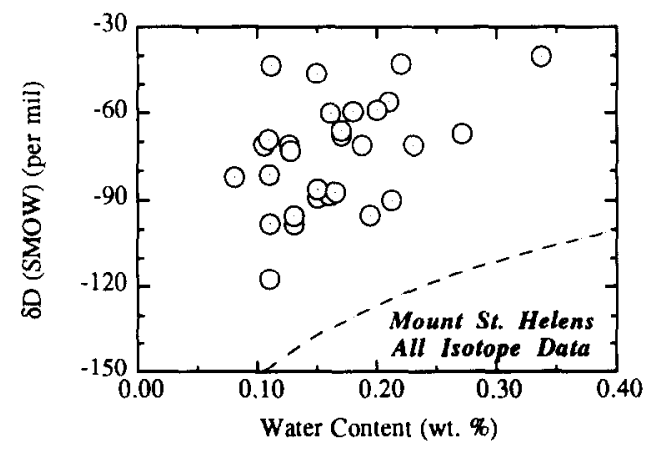

Fig. 5. Plot of $\delta \mathrm{D}$ versus water content for all Mount St. Helens domes samples included in Table 3 and in the Anderson and Fink $(1989,1990)$ studies. Although no trends are apparent, all points plot above and to the left of an open-system curve (dashed line) calculated using the assumptions made by Hoblitt and Harmon (1993) for the pre-October 1980 magma body. 


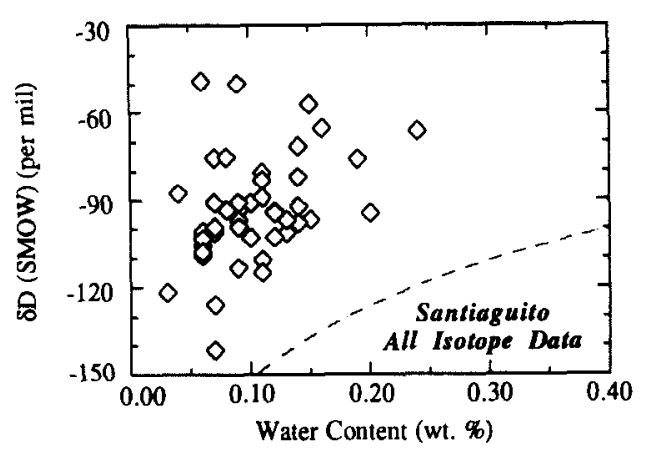

Fig. 6. Plot of $\delta \mathrm{D}$ versus water content for all samples from the surface of the Santiaguito dome. As in Fig. 5, the data are bounded on the lower right by an open system trend (dashed line) calculated for the Mount St. Helens magma body.

Based on our experience with the Mount St. Helens data, we tried to subdivide the Santiaguito samples according to effusion rate, age, vesicularity, and position before looking for better-defined degassing trends. Because the eruption has been uninterrupted, we cannot identify discrete batches of lobe-forming magma that were separated by repose periods. However, the eruption rates and styles of effusion have varied in a cyclic manner between relatively short (3-5 year) spurts and longer ( $10-12$ year), more quiescent periods (Rose, 1987). In order to compare samples whose effusion rates were roughly equivalent, we now restrict our attention to lava extruded during the periods of higher flux.

The Santiaguito complex is made of numerous overlapping lava flows extending away from four separate domes built through a combination of endogenous and exogenous growth. Determining the positions of samples relative to the vent and flow front (and hence their temporal sequence) can only be done unambiguously for the lava flows, so here we ignore samples collected from the proximal domes. Within the flows, distance from the vent can be roughly correlated with time of extrusion; the more distal samples represent lava that came out earlier, although rocks taken from a central channel will generally be younger than those from the adjacent marginal levees (e.g., Fink and Zimbelman, 1990). As most of our Santiaguito samples have low vesicularities, it is not necessary to differentiate between smooth and scoriaceous textures.

Fig. 7 shows isotopic data for smooth samples from various Santiaguito lava flows emplaced with relatively high eruption rates. The data are further subdivided into those from near-vent and flow-front positions (midflow samples are omitted). Despite including samples emplaced over a 70 year period, these two data subsets each reveal open-system or multistep open/closed system degassing, suggesting that each batch of magma erupted during a given 'spurt' had similar $\delta \mathrm{D}$ and water content values in the chamber and similar degassing histories during emplacement. The consistency in eruptive behavior exhibited during high extrusion rate lava flow production at Santiaguito (Rose, 1987) may therefore result from comparable styles of magmatic degassing during transit to the surface.

Our earlier discussion suggests that the clearest degassing trends should be observed in lava from discrete magma batches emplaced over a relatively short time interval, such as the open-system pattern seen in the October 1986 suite from Mount St. Helens (Fig. 3). At Santiaguito, comparable groupings do not exist because the eruption has been continuous. However, we have isolated smooth lava flow samples from various restricted time periods, assuming that these would reflect the evolution of relatively uniform batches of magma. Three of these subsets are shown in Fig. 8. Within each subgroup, $\delta \mathrm{D}$ declines in concert with water content. The 1958-1963 samples (Fig. 8a), which show the clearest trend, were quite closely spaced on the lava flow (Fig. 1), and thus were probably emplaced over the shortest time interval. In contrast, the two near-vent samples in the 1972-1975 data set (Fig. $8 \mathrm{~b}$ ) were probably erupted more than two years after the flow-front samples, during which time the source magma may have undergone a slightly different degassing history. The 1986-1992 data

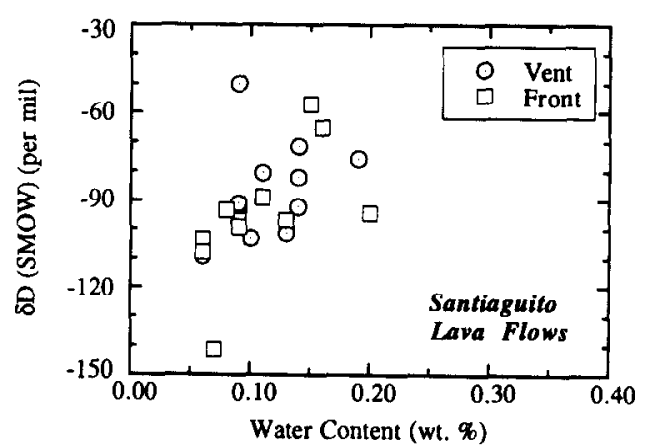

Fig. 7. Plot of $\delta \mathrm{D}$ versus water content for smooth near-vent and flow-front lava flow samples emplaced during periods of high extrusion rate ('spurts') at Santiaguito. Note that both sets are consistent with open-system trends. 

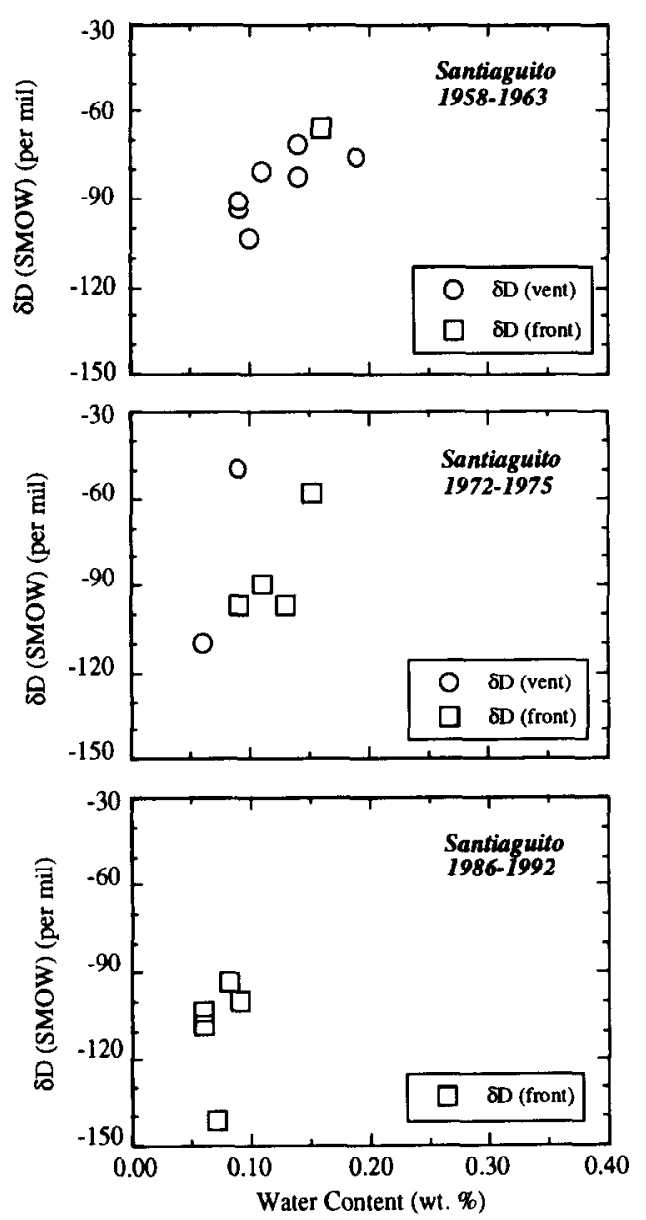

Fig. 8. Plot of $\delta D$ versus water content for smooth near-vent and flow-front lava flow samples emplaced during three eruptive spurts at Santiaguito: (a) 1958-1963; (b) 1972-1975; (c) 1986-1992. Note that each set of points defines an open-system trend.

(Fig. 8c) also define an open-system or multistep open/closed system trend, although one $\delta \mathrm{D}$ value appears anomalously low. In contrast to the early Mount St. Helens lobes, none of the Santiaguito subsets appear to exhibit any obvious kinetic degassing effects.

\section{Discussion}

As with all post- 1983 extrusions at Mount St. Helens, the October 1986 lobe is dominated by smooth lava. Smooth lava forms when eruption rates are low enough to allow thorough degassing of magma prior to its arrival at the surface. If the eruption rate is high enough to prevent adequate degassing in transit, the magma may experience an additional release of volatiles at the surface, forming a scoriaceous carapace. After the period of continuous growth at Mount St. Helens during 1983 and early 1984, extrusion of lava at the surface was increasingly inhibited by the weight and strength of the dome itself, as reflected in longer periods of precursory deformation and endogenous growth (Anderson and Fink, 1989, 1990; Fink et al., 1990). The large, strong dome apparently impeded the flow of lava to the surface, allowing more time for degassing in a shallow environment resulting in the formation of smooth lobes.

Studies of dome deformation and microlite growth suggest that all lava erupted during a particular episode comes directly from the chamber, rather than being degassed material stored in the conduit and dome interior between extrusive phases (Chadwick et al., 1988; Chadwick and Swanson, 1989; Cashman, 1992). Higher water contents in the final stages of the October 1980, December 1980, February 1981, June 1981, May 1985, May 1986 (Anderson and Fink, 1990) and October 1986 lobes therefore result from later magma moving more quickly to the surface through the opened conduit and dome (Jaupart and Allegre, 1991). We attribute the shift in Mount St. Helens lava texture from predominantly scoriaceous in pre-1983 lobes to predominantly smooth in post-1983 lobes to lower shortterm eruption rates and greater degassing prior to arrival at the surface caused primarily by the increased size and strength of the dome.

The subgroupings of Santiaguito samples depicted in Fig. 8 suggest that the scatter shown in the plot of all Santiaguito samples (Fig. 6) can be explained by two factors: superposition of several open-system degassing trends taking place in different batches of magma; and/or 'multi-step' open/closed system degassing like that described by Taylor (1991). Neither the temporally restricted Santiaguito data (Fig. 8) nor the October 1986 Mount St. Helens data appear to require a kinetic degassing process like that used to explain the isotopic signatures of smooth and scoriaceous samples from the early stages of Mount St. Helens dome growth. This difference is likely caused by the lower short-term eruption rates and longer and more contorted pathways that most of the Santiaguito and later Mount St. Helens magma experienced on the way to the surface. The restriction of kinetically controlled degassing to pre-1983 Mount St. Helens lobes (and 
possibly pre-1925 Santiaguito lavas) suggests that this mechanism may occur only in the early phases of dome growth when short-term eruption rates are somewhat elevated and the water contents are relatively low (less than about $0.5 \mathrm{wt} . \%$ ). This combination of conditions would inhibit exchange between the exsolved vapor and the water still remaining in the melt.

The similar textures of the Santiaguito and post- 1983 Mount St. Helens lavas, and the similarity in degassing styles of the Santiaguito and October 1986 lavas, may indicate that both domes attained a critical size and strength which reduced short-term eruption rates, allowed more time for degassing prior to the arrival of magma at the surface, and prevented scoria development. At Mount St. Helens, this condition was reached sometime during the continuous extrusion in 19831984 when the dome grew from approximately 31.8 to $53.2 \times 10^{6} \mathrm{~m}^{3}$. Santiaguito grew to a comparable volume between 1922 and 1925, and flows erupted during the subsequent spurt of 1928-1933 exhibited a smooth, blocky morphology (Rose, 1973, 1987). The temporary increase in scoria production after 1970 coincided with a shift from the El Brujo to the Caliente vent. Since Caliente lies above the main 1902 conduit, lava that it erupts has a shorter path to the surface, less time to degas prior to extrusion, and thus should develop more scoria than magma that traveled through nearly 1 $\mathrm{km}$ of dome to one of the more distal vents.

\section{Summary}

Although long-term lava dome growth rates are governed by magma supply and viscosity (Swanson et al., 1987), short-term eruption rates are influenced by the size, shape, and strength of the domes themselves (Fink et al., 1990, Stasiuk et al., 1993). Post-1983 Mount St. Helens lavas are similar to most of the post-1925 Santiaguito flows in degassing mechanisms and lack of scoriaceous carapace because both domes reached a critical size and strength, resulting in lower short-term eruption rates and more extensive degassing of lava en route to the surface.

This comparison of Santiaguito and Mount St. Helens volatile data suggests that lava collected from a growing lava dome can potentially reveal a great deal about degassing processes occurring in the chamber, conduit, and during surface flow, but only if these sam- ples are well constrained. Opportunities to further test these ideas should be provided by samples collected at recent and ongoing silicic dome eruptions at Redoubt (Alaska), Mount Unzen (Japan), Merapi (Indonesia), Bezymianny (Kamchatka) and elsewhere.

\section{Acknowledgements}

We thank Mike Colucci at Southern Methodist University for conducting the isotopic analyses, Rick Wessels for field assistance, Bobbie Myers, Don Swanson and Dan Dzurisin for logistical help at Mount St. Helens, and Sam Bonis for political guidance in Guatemala. Don Swanson and Sally Newman provided valuable reviews. This work was supported by grant EAR9018216 from the Petrology and Geochemistry Program of the National Science Foundation, grant NAGW 529 from the Planetary Geology and Geophysics Program at NASA, and a Black Hills State University Faculty Research grant.

\section{References}

Anderson, S.W. and Fink, J.H., 1989. Hydrogen isotopic evidence for extrusion mechanisms of the Mount St. Helens dome. Nature, 341: 521-523.

Anderson, S.W. and Fink, J.H., 1990. The development and distribution of lava textures at the Mount St. Helens dome. In: J.H. Fink (Editor), Lava Flows and Domes: Emplacement Mechanisms and Hazard Implícations. IAVCEI Proc. Volcanol., 2: $25-$ 46.

Anderson, S.W. and Fink, J.H., 1992. Crease Structures: indicators of emplacement rates and surface stress regimes of lava flows. Geol. Soc. Am. Bull., 104: 615-625.

Cashman, K.V., 1992. Groundmass crystallization of Mount St. Helens dacite, 1980-1986: A tool for interpreting shallow magmatic processes. Contrib. Mineral. Petrol., 109: 431-449.

Cashman, K.V. and Taggart, J.E., 1983. Petrologic monitoring of the 1981 and 1982 eruptive products from Mount St. Helens. Science, 221: 1385-1387.

Chadwick, W.W. Jr. and Swanson, D.A., 1989. Thrust faults and related structures in the crater floor of Mount St. Helens volcano, Washington. Geol. Soc. Am. Bull., 101: 1507-1519.

Chadwick, W.W., Swanson, D.A., Iwatsubo, E.Y., Heliker, C.C. and Leighley, T.A., 1983. Deformation monitoring at Mount St. Helens in 1981 and 1982. Science, 221: 1378-1380.

Chadwick, W.W. Jr., Archuleta. R.J. and Swanson, D.A., 1988. The mechanics of ground deformation precursory to dome-building extrusions at Mount St. Helens: 1981-1982. J. Geophys. Res., 93: $4351-4366$. 
Dobson, P.F., Epstein, S. and Stolper, E.M., 1989. Hydrogen isotope fractionation between coexisting vapor and silicate glasses and melts at low pressure. Geochim. Cosmochim. Acta, 53: 27232730.

Eichelberger, J.C. and Westrich, H.R., 1981, Magmatic volatiles in explosive rhyolitic eruptions. Geophys. Res. Lett., 8: 757-760.

Eichelberger, J.C. and Westrich, H.R., 1984. Degassing of magma in an obsidian flow and inferred degassing at depth. In: Proceedings of Workshop XIX: Active Tectonic and Magmatic Processes beneath Long Valley Caldera, CA. U.S. Geol. Surv., Open File Rep., 84-939: 147-150.

Eichelberger, J.C., Carrigan, H.R., Westrich, H.R., Price, R.H., 1986. Non-explosive silicic volcanism. Nature, 323: 598-602.

Fink, J.H. and Zimbelman, J.R., 1990. Longitudinal variations in rheological properties of lavas: Puu Oo basalt flows, Kilauea Volcano, Hawaii. In: J.H. Fink (Editor), Lava Flows and Domes: Emplacement Mechanisms and Hazard Implications. IA VCEI Proc. Volcanol., 2: 157-173.

Fink, J.H., Malin, M.C. and Anderson, S.W, 1990. Intrusive and extrusive growth of the Mount St. Helens dome. Nature, 348: 435-437.

Fink, J.H., Anderson, S.W. and Manley, C.R., 1992. Textural constraints on effusive silicic volcanism: Beyond the permeable foam model. J. Geophys. Res., 97: 9073-9083.

Hoblitt, R.P. and Harmon, R.S., 1993. Bimodal distribution of cryptodome dacite from the 1980 eruption of Mount St. Helens, Washington. Bull. Volcanol., 55: 421-437.

Jaupart, C. and Allegre, C.J., 1991. Gas content, eruption rate and instabilities of eruption regime in silicic volcanoes. Earth Planet. Sci. Lett., 102: 413-429.

Moore, J.G., Lipman, P.W., Swanson, D.A. and Alpha, T.R., 1981, Growth of lava domes in the crater, June 1980-January 1981. In: P.W. Lipman and D.R. Mullineaux (Editors), The 1980 Eruptions of Mount St. Helens, Washington. U.S. Geol. Surv., Prof. Pap., 1250: 541-548.

Newman, S., Epstein, S. and Stolper, E.M., 1988. Water, carbon dioxide, and hydrogen isotopes in glasses from the ca. 1340 eruption of the Mono Craters, California: Constraints on degas- sing phenomena and initial volatile content. J. Volcanol. Geotherm. Res., 35: 75-96.

Rose, W.I., 1972. Santiaguito volcanic dome, Guatemala. Geol. Soc. Am. Bull., 83: 1413-1434.

Rose, W.I., 1973. Nuée ardente from Santiaguito Volcano, April 1973. Bull. Volcanol., 38: 365-371.

Rose, W.I., 1987. Volcanic activity at Santiaguito Volcano, 19761984. In: J.H. Fink (Editor), The Emplacement of Silicic Domes and Lava Flows. Geol. Soc. Am., Spec. Pap., 212: 17-28.

Rose, W.I., Pearson, T. and Bonis, S., 1977. Nuee ardente eruption from the foot of a dacite lava flow, Santiaguito Volcano, Guatemala. Bull. Volcanol., 40: 53-70.

Stasiuk, M.V., Jaupart, C. and Sparks, R.S.J., 1993, On the variations of flow rate in non-explosive lava eruptions. Earth Planet. Sci. Lett., 114: 505-516.

Swanson, D.A. and Holcomb, R.T,, 1989. Regularities in growth of the Mount St. Helens dacite dome: 1980-1986. In: J.H. Fink (Editor), Lava Flows and Domes: Emplacement Mechanisms and Hazard Implications. IAVCEI Proc. in Volcanol., 2: 3-24.

Swanson, D.A., Dzurisin, D., Holcomb, R.T., Iwatsubo, E.Y., Chadwick, W.W. Jr., Casadevall, T.J., Ewert, J.W. and Heliker, C.C., 1987, Growth of the lava dome at Mount St. Helens, Washington. In: J.H. Fink (Editor), The Emplacement of Silicic Domes and Lava Flows. Geol. Soc. Am., Spec. Pap., 212: 1-16.

Taylor, B.E.. 1986. Magmatic volatiles: Isotopic variations of C, H, and S. Mineral. Soc. Am., Rev. Mineral., 16: 185-226.

Taylor, B.E., 1991. Degassing of Obsidian Dome rhyolite, Inyo volcanic chain, California. In: H.P. Taylor, J.R. O'Neil and I.R. Kaplan (Editors), The Geochemical Society, Spec. Publ., 3: 339-353.

Taylor, B.E., Eichelberger, J.C. and Westrich, H.R., 1983. Hydrogen isotopic evidence of rhyolitic degassing during shallow intrusion and eruption. Nature, 306: 541-545.

Westrich, H.R., Stockman, H.W. and Eichelberger, J.C., 1988. Degassing of rhyolitic magma during ascent and emplacement. J. Geophys. Res., 93: 6503-6511.

Williams, S.N. and Self, S., 1983. The October, 1902, plinian eruptions of Santa Maria volcano, Guatemala. J. Volcanol. Geotherm. Res., 16: 33-56. 